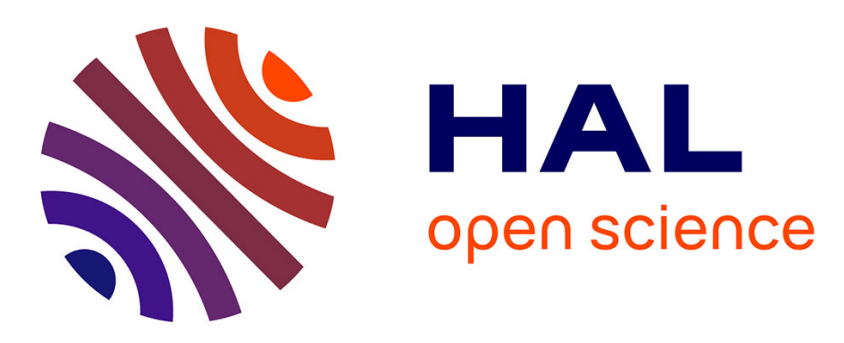

\title{
In Vivo Medulloblastoma Modeling
}

Liliana Mirabal-Ortega, Magalie Larcher, Morgane Morabito, Chloé Foray, Bertrand Duvillié, Alain Eychène, Celio Pouponnot

\section{To cite this version:}

Liliana Mirabal-Ortega, Magalie Larcher, Morgane Morabito, Chloé Foray, Bertrand Duvillié, et al.. In Vivo Medulloblastoma Modeling. Brain Tumors, pp.39-58, 2020, 10.1007/978-1-0716-0856-2_2 . hal-03044841

\section{HAL Id: hal-03044841 https://hal.science/hal-03044841}

Submitted on 18 Dec 2020

HAL is a multi-disciplinary open access archive for the deposit and dissemination of scientific research documents, whether they are published or not. The documents may come from teaching and research institutions in France or abroad, or from public or private research centers.
L'archive ouverte pluridisciplinaire HAL, est destinée au dépôt et à la diffusion de documents scientifiques de niveau recherche, publiés ou non, émanant des établissements d'enseignement et de recherche français ou étrangers, des laboratoires publics ou privés. 


\section{In vivo Medulloblastoma modeling}

Liliana Mirabal-Ortega ${ }^{1,2,3,4,5}$, Magalie Larcher ${ }^{1,2,3,4,5}$, Morgane Morabito ${ }^{1,2,3,4,5}$, Chloé Foray $^{1,2,3,4,5}$, Bertrand Duvilliée ${ }^{1,2,3,4,5}$, Alain Eychène ${ }^{1,2,3,4,5}$ and Celio Pouponnot ${ }^{1,2,3,4,5,6}$

${ }^{1}$ Institut Curie, Orsay F-91405, France

${ }^{2}$ INSERM U1021, Centre Universitaire, Orsay F-91405, France

${ }^{3}$ CNRS UMR 3347, Centre Universitaire, Orsay F-91405, France

${ }^{4}$ University Paris Sud - Paris Saclay, F-91405 Orsay, France

${ }^{5}$ PSL Research University,

${ }^{6}$ Corresponding author

Corresponding author :

Celio POUPONNOT, $\mathrm{PhD}$

Institut Curie - Recherche

Bâtiment 110, Centre Universitaire

Rue Henri Becquerel

CS 90030

91401 ORSAY Cedex

E-mail : celio.pouponnot@curie.fr

Tel. +33169863079

Fax. +33169863051

$\underline{\text { Running title : Modeling medulloblastoma }}$

Key words: Medulloblastoma, animal models, Patient-derived xenograft (PDX), cerebellar progenitors, cerebellum, orthotopic grafting 


\begin{abstract}
Medulloblastoma (MB), the most frequent malignant brain tumor in children, is localized in the cerebellum. The standard care includes surgery, radiotherapy and chemotherapy leading to an overall survival (OS) of $70-80 \%$ but survivors suffer from severe side effects. Based on gene expression, MB is divided in four different molecular subgroups: WNT, SHH, Group 3 (G3) and Group 4 (G4), which differ in terms of clinics, prognosis, genetic alterations and cell of origin. The WNT group is characterized by the activation of the WNT/ $\beta$-catenin signaling pathway and displays the best prognosis. The SHH group is driven by deregulation of the $\mathrm{SHH}$ signaling pathway and has an intermediate prognosis. G3 and G4 are less characterized. In contrary to the SHH and WNT groups, no specific alteration of a given signaling pathway has been described. G3 is the group with the worse prognosis. Few recurrent genetic alterations have been characterized including MYC amplification in less than 20\% of G3 tumors. Nevertheless, all G3-MBs overexpress MYC through mechanisms not completely understood. G3-MB also express an abnormal photoreceptor differentiation program found in the retina but not in the cerebellum during normal development. It has been shown that NRL and CRX, two master transcription factors (TF) of the photoreceptor lineage, are required for the establishment this program as well as for G3 tumor maintenance. G4 has an intermediate prognosis and the most frequent alteration is the overexpression of PRDM6. It has been recently proposed that this group could be driven by activation of an ERBB4-SRC signaling.

Established cell lines and patient-derived xenografts (PDXs) are available to study MB. The different groups of $\mathrm{MB}$ have also been modeled in vivo using either genetically engineered mouse models (GEMM) or by orthotopic transplantation of mouse cerebellar progenitors modified to overexpress oncogenes and/or to inactivate tumor suppressors. Here, we provide the readers with tools and information that allow MB modeling in vivo. We describe how to purify granular cell cerebellar progenitors or PDXs and to culture them in vitro in order to modulate gene expression by lentiviral infection. We provide protocols for the retrovirus production and infection. We also describe the experimental procedures for orthotopic grafting in the cerebellum, which is used to assess how genetic modifications alter in vivo tumor formation of reinjected modified PDXs cells or GCPs.
\end{abstract}




\section{Introduction}

In developing countries, pediatric tumors are the second most frequent cause of death in children older than one. Among childhood cancers, leukemia is the most prevalent, representing about $30 \%$ of the cases, while tumors of the central nervous system (CNS) are the most common solid tumors $(20 \%)$ [33].

Medulloblastoma (MB) is a pediatric CNS tumor originating in the cerebellum. Although rare, it represents the most malignant brain tumor in childhood. It arises at a median age of seven, with more than $70 \%$ of patients that are below the age of ten, but it can be also diagnosed in adolescents and adults. Patients with MB present symptoms such as intracranial pressure, hydrocephalus, nausea, vomiting and balance or motor coordination problems [6]. Different histological variants have been described including classic, desmoplastic and large cells/anaplastic (LC/A) MB [20]. Metastases are found in $~ 30 \%$ of patients at diagnosis and are associated with a bad prognosis. They are mainly found in leptomeninges, although systemic metastases can be observed in very rare patients with advanced and highly treated disease [20].

The current standard care for MB patients is composed of surgery, followed by radiotherapy of the entire cranio-spinal axis and association of different chemotherapies. This treatment scheme is applied to all patients except infants below the age of three, who are spared of radiotherapy due to the high toxicity on the developing brain. This heavy multimodal treatment has allowed reaching an overall survival (OS) of $80 \%$ but at the cost of severe side effects including neurological and cognitive deficits, endocrine disorders, hearing loss and, possibly, secondary cancers [20]. When relapse is observed, very few therapeutic options remain and the outcome is almost always fatal [20].

\subsection{The MB Groups}

To better understand the disease and stratify patients, molecular analyses have established a novel classification of the disease. As expected and observed in many different cancers, intertumor heterogeneity has been uncovered. MB does not represent a single entity but gathers at least four distinct groups differing in their molecular and clinical characteristics, prognosis and their cell of origin [20, 29]. These four groups - WNT, SHH, Group 3 (G3) and Group 4 (G4) - have first been identified through transcriptomic analyses $[4,15,18,30]$ and further validated by DNA methylation profiling [26] and proteomic analyses [1, 7, 23] (Table 1). Recently, three different studies have shown that each group could be further subdivided into subtypes 
providing a better prognostic value. However, the number and nature of these subtypes are variable between these studies and no consensus has yet been reached [3, 17, 25].

\section{$\underline{\text { The WNT Group }}$}

The WNT group, as highlighted by its name, is driven by the activation of the $\mathrm{WNT} / \beta$-catenin signaling pathway. It represents $10-15 \%$ of all $\mathrm{MBs}$ and is usually found in older patients, adolescents and adults. WNT group displays the most favorable outcome with an OS at 5 years over $95 \%$. It is in most cases of classic histology and is very rarely metastatic at diagnosis. Clinical trials are ongoing to evaluate whether treatment de-escalation could be an option in order to decrease side effects. It should be noticed that adult WNT-MBs have a less favorable outcome [20,32]. Different pieces of evidence, including a genetically engineered mouse model (GEMM) based on the concurrent conditional expression of a mutant Ctnnb1 (stabilized form of $\beta$-catenin) and inactivation of TP53, led to propose that the cell of origin of the WNT group is a lower rhombic lip progenitor residing in the brainstem outside the cerebellum [9].

\section{$\underline{\text { The SHH Group }}$}

The SHH-MBs represent $25-30 \%$ of MB cases and are driven by deregulation of the cognate SHH signaling pathway. Metastases are found in $20 \%$ of SHH-MB at diagnosis. It is associated with the three main types of histology: desmoplastic, classic and LC/A [20]. It should be emphasized that desmoplastic histology is mainly found in SHH-MBs and virtually absent in other groups and presents a better prognosis. This group is the most prevalent in infants below the age of three and in adults. It is less frequent in children and adolescents. Overall, it has an intermediate prognosis around $75 \%$ of survival. Within this group, OS can be refined according to the different subtypes recently described $[3,25]$. Some SHH subtypes display an extremely bad prognosis while others have a predictive very good outcome. The granule cell progenitors (GCPs), which are highly proliferative during post-natal cerebellar development, have been clearly demonstrated to be the cell of origin of SHH-MB [24, 34] and several mouse models have been generated by targeting genetic alterations in this cell type (see below).

While SHH and WNT groups are driven by the deregulation of specific signaling pathways, alterations that specifically drive G3 and G4 are much less characterized. Moreover, much less mutations and recurrent alterations are found in these two latter groups.

\section{$\underline{\text { Group } 3}$}


G3 represents 20-25\% of all MB cases and has the worse prognosis with a 5-year OS of $60 \%$. These tumors usually occur in infants or young children. They display mainly a classic or LC/A histology and are highly metastatic at diagnosis (40-50\%). Tumor recurrence is usually not found at the primary tumor bed but rather at metastatic sites [20]. While MYC amplification is found in less than $20 \%$ of G3, all G3-MBs express high levels of MYC through unknown mechanisms. Accordingly, G3 tumors are characterized by a MYC target gene signature with high expression of ribosomal genes, genes involved in mRNA processing, transcription and translation $[1,4,7,15]$. MYCN is also amplified in 5\% of cases. Beside MYC amplification, GFI1 transcription factors (GFI1 and GFI1B) are overexpressed in 15\% of patients, mostly through enhancer hijacking mechanisms [19]. Their role as a co-driver together with MYC has been validated using animal models [19, 31]. Moreover, G3 tumors display very surprising characteristics. They express a set of genes usually turned on specifically in the photoreceptor cells of the retina but never in the cerebellum [4, 8, 15]. Thus, G3 shows an aberrant identity unrelated to its tissue of origin, the cerebellum. We recently showed that NRL and CRX, two master transcription factors (TF) of the photoreceptor lineage, establish this aberrant identity. Importantly, they are also required for MB growth [8]. This challenges the widely accepted concept of lineage addiction, which postulates that cancer cells depend on the identity of a given cell lineage from which cancer grows. This work shows that cancer cells can be driven by an abnormal identity unrelated to its tissue of origin. As the SHH-MB, G3 have been further divided into subtypes with different clinical outcomes. Indeed, it has been shown that one subtype characterized by high MYC expression, including MYC amplified tumors, shows the worse prognosis [3]. The cell of origin of G3 tumors remains a matter of debate. It has been suggested that $\mathrm{G} 3$ cells could arise either from $\mathrm{CD} 133^{+}$cerebellar neural stem cells [21] or from the granule cell progenitors (GCPs) (see below).

\section{$\underline{\text { Group } 4}$}

G4 is the most prevalent MB group found in 35-40\% of patients. Its histology is most frequently classic but LC/A histology is also encountered at lower frequency. It is found in older patients, mainly older children, adolescents and adults. It is of intermediate prognosis with an OS at 5 years around $75 \%$. It is also frequently metastatic at diagnosis (35\%-40\%) and, as in G3-MB, relapses are more frequent at metastatic sites [20]. The most frequent alteration, found in around 
$20 \%$ of cases, is an enhancer hijacking mechanism that leads to strong overexpression of PRDM6, a putative lysine-methyl transferase. PRDM6 alteration is considered as a putative driver event in G4, but its exact role has not been clearly demonstrated yet [17]. Recently, proteomic and phospho-proteomic studies have proposed that $\mathrm{G} 4$ could be driven by activation of an ERBB4-SRC signaling. The relevance of SRC activation has been further validated with the development of an animal model based on in utero electroporation and that displays some characteristics of G4 tumors [7].

\subsection{MB Models}

As in other cancers, established cell lines and patient-derived xenografts (PDX) are frequently used in the MB field. The different groups of MB have been modeled in vivo either by genetically engineered mouse models (GEMM) and/or by orthotopic transplantation of modified mouse cerebellar progenitors manipulated to overexpress oncogenes and/or to inactivate tumor suppressors. In contrast, no patient-derived organoid has been established for MB so far and, in contrast to Glioblastoma, primary cultures from patient samples can be maintained for only very short-term in MB and are not commonly used.

Interestingly, the stable expression of a Luciferase gene in all these models allowed a longitudinal follow-up of tumor growth upon orthotopic transplantation into the cerebellum of immunodeficient mice by bioluminescence quantification. This allows assessing the impact of gene overexpression, gene extinction or drug treatment on tumor growth. We have used this system on cell lines or MB-PDX to demonstrate the role of the transcription factor NRL, a master regulator of photoreceptor development, on Group 3 MB growth [8].

In the following section, we will give a brief overview of some in vivo models used in the MB field. We do not attempt to provide an exhaustive description of them.

\subsubsection{Patient-derived xenografts}

Patient-derived xenografts (PDX) have become a widely used model in cancer research since they are presumed to faithfully recapitulate the original tumors from which they derived. PDXs are established from fresh surgical MB material that is grafted subcutaneously or orthotopically directly into the cerebellum of immunocompromised mice (Nod Scid Gamma mice for the establishment). The PDXs are maintained in vivo by serial passages in immuno-deficient mice either subcutaneously or in the cerebellum. It has been demonstrated that PDXs can be 
established from the different MB groups and remain stable across serial sub-transplantations [35] although some subclonal selection can occur [2]. Very recently, a biobank has been established allowing the availability of 15 MB PDXs including one WNT-MB, four SHH-MBs, seven G3-MBs and three G4-MBs [2]. Five out of the seven G3 PDXs harbor MYC amplification. The establishment rate for MB was around 35\%. It should be noticed that PDXs have been mostly established from high-risk MBs indicating that aggressive tumors are more favorable to grow as PDXs. When compared to subcutaneous grafting, initial grafting in the cerebellum may be more efficient and might allow a better grafting efficiency for less aggressive tumors. Important information is provided on these PDXs including transcriptomic and whole exome sequencing data: https://research.fhcrc.org/olson/en/btrl.html and https://hgserver1.amc.n1/cgi-bin/r2/main.cgi?\&dscope=PDX_OLSON\&option=about_dscope. PDX models have been used, for example, to validate important players in MB biology [8] or to investigate different potential therapies such as Smoothened inhibitors in the SHH group [14], the CDK4/6 Palbociclib inhibitor for SHH and G3 groups [5], or anti-BCL therapy in the G3 [8]. In the section 2.1 we provide the experimental procedure to culture these PDXs in order to overexpress or downregulate gene expression by retroviral infection and to investigate how this genetic manipulation can affect tumor growth orthotopically.

\subsubsection{Genetically-engineered mouse models (GEMM)}

Although highly time consuming, laborious and expensive, genetically-engineered mouse models (GEMM) have proven to be one of the most valuable tools in cancer research. Such models are based on the editing of the mouse genome, including gene deletion (knock-out mice), gene mutation (knock-in mice) or overexpression (transgenic mice). In contrast to other models, GEMMs develop de novo tumors in their natural and immune proficient environment allowing to carefully study the different steps in tumorigenesis, from initiation to advanced cancer states [13]. GEMMs have allowed to validate different genetic drivers in MB as well as to identify the cell of origin of different groups, especially for the SHH and WNT groups.

These models have been widely used to study the SHH group. The first MB GEMM was described in 1997. It consists of PTCH1 ${ }^{-/+}$mice that develop medulloblastoma at low frequency, in about $20 \%$ of cases. Noteworthy, these MBs have lost the second allele of PTCH1 [10]. This and other ubiquitous or conditional knock-out mouse models have been widely used to validate different cooperating oncogenic events in this group. Moreover, different conditional GEMM 
models have allowed to firmly establish that SHH-MB originates from GCPs and that a GCP identity is crucial for tumor formation [24, 34].

A unique GEMM has been described for the WNT tumors. Several observations support the fact that WNT-MB might arise outside the cerebellum, from cells in the dorsal brainstem, which originate from the lower rhombic lip [9]. Accordingly, a knock-in mice, in which the expression of an activated mutated form of $\beta$-catenin can be conditionally induced in different cell progenitors, have shown that activated $\beta$-catenin has no effect on cerebellar progenitors but induces abnormal accumulation of cells in the dorsal brainstem.

Using transgenic mice, it has been shown that NMYC overexpression in the cerebellum induces different type of MBs including G3, G4 and SHH [27, 28].

\subsubsection{Orthotopic transplantation of modified/transformed cerebellar progenitors}

To get insights into the cell of origin of the G3 group, a model originally developed for SHHMB by Dr. Roussel's lab has been used. This model relies on the modification of murine cerebellar progenitors that are then orthotopically grafted in animals. For the original SHH model, GCPs were purified from $\mathrm{p} 53^{-/-}:$Ink $4 \mathrm{C}^{-/-}$mice at early postnatal stages between $\mathrm{p} 2$ to p8, when these progenitors are still proliferating. Oncogenic hits such as overexpression of NMYC were introduced by retroviral infection. The resulting modified GCPs, when grafted into the cerebellum of immunocompromised mice, led to the formation of SHH-MB [36]. A modified experimental procedure allowed G3 tumors formation when other oncogenic combinations were used. For instance, the loss of p53 together with MYC (c-MYC) overexpression in GCPs form G3-MB when transplanted into the cerebellum of nude mice. These results led to propose that GCPs may be the cell of origin of G3 [12].

Another model described for G3 is based on the retroviral transduction of another cerebellar cell population that expresses the neural stem cell (NSC) marker CD133 (prominin-1) [21]. It has been subsequently demonstrated that G3 tumors can be modeled when these cerebellar stem cells are engineered to overexpress a stabilized form of MYC together with a dominant negative form of p53 (DN-p53) and are subsequently transplanted in the cerebellum of NSG mice [21]. This model supports the idea that G3 may arise from $\mathrm{CD}_{13} 3^{+}$cerebellar NSCs.

Noticeably, while these two types of modified progenitors could be in principle transplanted back into syngeneic mice, only immunodeficient animals were used as recipients in published 
reports. Indeed, our own data tend to indicate that transplantation in syngeneic animals is much less efficient for unknown reasons.

Moreover, since G3 can be modeled from different cerebellar progenitors or NSC, its cell of origin remains elusive. Even more provokingly, using in utero electroporation leading to overexpression of MYC and a dominant negative form of TP53 it has been shown that G3-MB can arise from different cerebellar progenitors. Thus, it has been proposed that G3-MB is mainly driven by specific oncogenic hits, in particular MYC overexpression, rather than its deregulation in a specific cell of origin [11].

It is important to mention that while all the above models indeed display G3 characteristics, they all combine MYC overexpression with p53 inactivation. However, neither p53 loss nor its mutation is found in G3 at diagnosis [20], questioning the relevance of these models. Nevertheless, these models were used to validate the driving role of GFI-1 TF in G3 tumors (see above). It has been shown that retroviral mediated overexpression of MYC together with GFI-1 both in $\mathrm{CD}_{133^{+}}$cerebellar NSC [19] or in GCP [31] can induce G3-MB when transplanted. These models based on the in vitro transformation of GCPs by MYC and GFI1 are described in the following section.

\section{Experimental tools to model and study the biology of MB in vivo}

In the following sections, we describe the short-term in vitro culture of PDXs that allows gene expression manipulation by retroviral infection. We next provide information on MB modeling using the modified GCP culture. We provide protocols for the purification of these cells and their culture conditions. We also describe retroviral production and infection allowing gene expression manipulation in PDXs and GCPs. Finally, we provide a description of the experimental procedure to perform orthotopic grafting in the cerebellum, which is used to reinject both PDXs cells and GCPs.

\subsection{Patient-derived xenografts (PDXs)}

Patient-derived xenograft (PDX) model constitutes an essential tool to study MB. It better recapitulates heterogeneity and molecular features of patient tumors compared to in vitro models. For PDX establishment, tumor tissues freshly isolated from untreated patients are inoculated into immunodeficient mice, usually NSG mice, where they can be maintained and serially passaged either subcutaneously or orthotopically in the cerebellum. Cells from these 
PDXs, when cultured in vitro, can be engineered to knock-down (KD) or overexpress a given gene, whose role in MB can be subsequently studied. Once these modified cells are grafted either subcutaneously or orthotopically into the cerebellum of Nude mice, it is possible to evaluate the effect of the expression of this specific gene in MB tumor biology. As an example of such an approach, we have shown that NRL, a master transcription factor of the photoreceptor lineage in the retina, is critical for G3-MB maintenance [8]. To this end, cultures of different G3 PDXs were established and cells from PDXs were manipulated using retroviruses to induce either NRL KD or overexpression. The effect of these modifications on MB tumor growth was then evaluated in vivo, by performing orthotopic grafting of PDXs cells in Nude mice, allowing us to establish NRL requirement for MB growth.

\subsubsection{Short term in vitro cultures from PDXs}

PDXs extracted from animals are processed to be short-term cultured to allow genetic modifications of the cells. PDXs are first grown in the fat pad neck of mice (NMRI Nude mice, Janvier Labs) until they reach a volume of around $1.5 \mathrm{~cm}^{3}$. PDXs are extracted from freshly euthanized animals using sterile forceps, scalpels and scissors. Once extracted, the PDX is placed in a Petri dish and any adjacent non-tumor or necrotic tissue should be removed. Using a scalpel, the tumor is cut in small pieces (around $3-4 \mathrm{~mm}^{3}$ ) that are then disaggregated by enzymatic digestion. To that end, pieces of tumor are covered by the dissociation buffer $(2.5 \mathrm{ml}$ of buffer containing Neurobasal medium (Gibco) supplemented with 1mg/ml DNase (Worthington), $2.5 \mathrm{mg} / \mathrm{ml}$ Collagenase P (Roche), $2.5 \mathrm{mg} / \mathrm{ml}$ Collagenase/Dispase (Roche) and B27 supplement without vitamin A (Gibco)) and incubated at $37^{\circ} \mathrm{C}$ for 30 minutes ${ }^{1}$. The suspension is filtered using a $40 \mu \mathrm{m}$ cell strainer (Sigma) to remove debris. The cell strainer is then rinsed with $10 \mathrm{ml}$ of Neurobasal medium and the filtrate is centrifuged at $520 \mathrm{~g}$ for 5 minutes. After centrifugation, the cell pellet is resuspended in a buffer containing $1 \mathrm{ml}$ of Neurobasal medium supplemented with $0.5 \mathrm{mg} / \mathrm{ml}$ DNase, $0.35 \%$ D-Glucose (Sigma) and $2 \mathrm{ml}$ of CMF-PBS pH7.4 buffer $(\mathrm{NaCl} 0.14 \mathrm{M}, \mathrm{KCl} 4 \mathrm{mM}$, Glucose $11.1 \mathrm{mM}$, NaH2PO4 H2O $3.2 \mathrm{mM}$, KH2PO4 $3.2 \mathrm{mM}$, NaHCO3 $0.004 \%$ ). The different cell populations are separated using discontinuous Percoll gradient (Sigma), constituted of two phases, Percoll 35\% - Percoll 60\%. Percoll dilutions are prepared in CMF-PBS-EDTA (2.5mM final) buffer. Trypan blue solution $0.4 \%$ (Gibco) is added to the Percoll $60 \%$ solution to better visualize the cells. The $3 \mathrm{ml}$ cell suspension is deposited on the top of the Percoll gradient and centrifuged at $1800 \mathrm{~g}$ for 13 minutes with minimal acceleration and break (Eppendorf Centrifuge 5810R). At the end of centrifugation, cells at the interface of Percoll 60\%-35\% are collected and transferred into a 
$15 \mathrm{ml}$ tube filled with CMF-PBS to obtain a final volume of $15 \mathrm{ml}$. Cells are then centrifuged at $520 \mathrm{~g}$ for 5 minutes to remove the remaining Percoll solution. Finally, cells are seeded at a concentration of $2 \times 10^{6}$ cells $/ \mathrm{ml}$ in low attachment Corning ${ }^{\circledR}$ flasks or plates to prevent adhesion since PDX cells are grown in neurosphere conditions. PDX MB primary cultures are maintained in Neurobasal medium (Gibco) supplemented with B27 supplement without Vitamin A (Gibco), 0.012\% BSA (Sigma), 1\% Penicillin/Streptomycin, 1\% L-glutamine (Invitrogen), $12.5 \mathrm{ng} / \mathrm{ml}$ of Human bFGF (Peprotech), $12.5 \mathrm{ng} / \mathrm{ml}$ of Human EGF (Peprotech) ${ }^{2}$. This culture can be subjected to retroviral infection after $2 \mathrm{~h}$ of incubation at $37^{\circ} \mathrm{C}$ (see below for the description of the protocol).

\subsection{Culture of Granular Cell Progenitors (GCPs)}

MYC is overexpressed in all G3 tumors but, although necessary, it is not sufficient to give rise to G3-MB and therefore requires additional oncogenic hits. This was shown using the G3-MB mouse models based on orthotopic grafting of modified GCPs or cerebellar stem cells. Indeed, overexpression of MYC itself in these cells does not induce MB formation, while its combination with p53 inactivation or GFI-1 overexpression does [12, 19, 21, 31]. As described for the GFI-1 TFs, these models are particularly suited to validate novel G3 driver genes by testing their ability to cooperate with MYC to induce MB. For these models, GCPs need to be isolated, shortly cultured in vitro and genetically manipulated to be then grafted into the cerebellum of mice. Here, we described how to perform these different steps.

\subsubsection{Cerebella dissection and GCPs isolation}

For cerebella dissection, pups (aged between P5 and P8) are decapitated and the skin from the dorsal part of the head is removed using sterile scissors and forceps. The brain along the skull is dissociated from the rest of the head using forceps. The skull is then carefully removed by pulling it out from the front to the cerebellum, and the brain is transferred into a plate containing cold CMF-PBS. Meninges are scratched using very thin forceps under binocular loupes, paying attention not to damage the cerebellum, which is then separated from the rest of the brain. It is important to fully remove the meninges to avoid contamination of the GCP culture. All the manipulations should be performed at $4^{\circ} \mathrm{C}$.

After dissection, cerebella are transferred into polypropylene conical tubes $(15 \mathrm{ml})$ (2 or 3 cerebella per tube) containing $1 \mathrm{ml}$ of a Trypsin/DNase solution (10mg/ml Trypsin (Gibco), $1 \mathrm{mg} / \mathrm{ml} \mathrm{DNase,} 0.006 \mathrm{M} \mathrm{NaOH}, 1.5 \mathrm{mg} / \mathrm{ml} \mathrm{MgSO} 47 \mathrm{H} 2 \mathrm{O}$ ) and incubated at $37^{\circ} \mathrm{C}$ for 5 minutes. 
Then, the Trypsin/DNase solution is carefully removed and the cerebella are resuspended in 1 $\mathrm{ml}$ of DNase solution (Neurobasal medium supplemented with $0.5 \mathrm{mg} / \mathrm{ml}$ DNase and $0.35 \%$ DGlucose) and the tissue is mechanically dissociated by successively pipetting up and down with a $1 \mathrm{ml}$ micropipette and then with a syringe with $20 \mathrm{G}$ and, then, $23 \mathrm{G}$ needles. Each step is done approximately 15 times. The suspension is then centrifuged at $720 \mathrm{~g}$ for 5 minutes at $4^{\circ} \mathrm{C}$, the cell pellet is resuspended in $1 \mathrm{ml}$ of the DNase solution described above and $2 \mathrm{ml}$ of CMF-PBS $\mathrm{pH7.4}$ buffer is then added. To separate the different cell types, the $3 \mathrm{ml}$ cell suspension is centrifuged through a 35\%-60\% Percoll gradient as described above (Section 2.1.1). The cell pellet is resuspended in 50 $\mu 1$ of DNase solution and then GCP culture medium (Neurobasal medium supplemented with B27 supplement, 1\% Penicillin/Streptomycin, 0.2\% Fungizone, $1 \%$ L-glutamine (Invitrogen), SPITE medium supplement (Sigma), 0.1mM N-acetyl cysteine (Sigma), 0.45\% D-glucose, Oleic acid albumin/Linoleic acid (Sigma)) is added. Cells are then plated in a $35 \mathrm{~mm}$ diameter culture dish and incubated at $37^{\circ} \mathrm{C}$ during a period of time between $45 \mathrm{~min}$ and $2 \mathrm{~h}$. This step allows eliminating adherent cells, such as astrocytes, microglia, etc. Then, plates are gently flushed with a $1000 \mu 1$ micropipette in order to recover cells that are in suspension and slightly adherent. Cells are plated at $2 \times 10^{6} \mathrm{GCPs} / \mathrm{ml}$ in culture medium containing $0.2 \mu \mathrm{g} / \mathrm{ml}$ Sonic hedgehog (R\&D Systems). Of note, GCPs in culture are quite fragile, making it difficult to keep viable cultures for several days ${ }^{3}$.

\subsection{Retroviral production}

PDX cells or GCP cultures can be subjected to lentiviral infection in order to overexpress or KD (shRNA-mediated gene silencing) genes as previously described [8]. The use of lentiviral systems for modifying cells involves the production of retroviral particles that encode the gene of interest. We use retroviral defective systems that require a backbone retroviral construct that allows gene overexpression (pMIGR (also named MIGR1) (addgene https://www.addgene.org/27490/) or pMSCV vectors (addgene, https://www.addgene.org/86537/) or shRNA-mediated gene knock-down (pLKO vector (a shRNA library is available at SIGMA https://www.sigmaaldrich.com/life-science/functionalgenomics-and-rnai/shrna/library-information/vector-map.html), a packaging vector (encoding the gag/pol gene) and a plasmid encoding the envelope gene. The pMIGR or pMSCV vectors contain an IRES that allows the translation of the gene of interest and the GFP gene from the same cistron. Infected cells can be FACS-sorted using this marker. Other derivatives of these vectors can be found with different markers including the luciferase gene allowing a noninvasive follow-up of tumor growth by bioluminescence imaging and quantification. This tracer 
is particularly useful when cells are orthotopically grafted in the brain or the cerebellum (see below). On the other hand, to induce stable KD of genes of interest, lentiviral particles are produced using the pLKO.1-TRC vector, commonly used for the expression of shRNAs. pLKO-based vectors contain a selectable marker, the puromycin resistance gene (other resistant genes being also available), making possible the selection of infected cells by adding the antibiotic to the culture media. The choice of the packaging vector and of the envelope encoding plasmid depend on the backbone vector and the species of the cells to be infected, respectively. For example, when using the pLKO vector to infect human PDXs, we used the psPAX and pMD2/VSVG plasmids. The latter allows producing amphotropic retroviral particles that can infect both human and rodent cells. For murine GCP culture, the pMIGR (or MIGR1) together with the pCMV-Gag/Pol [22] and the pSV-E-MLV plasmids [16] are used. The latest plasmid encodes an ecotropic envelope allowing infection of mouse and rat cells. To produce retroviruses, HEK293T cells seeded at a density of $1 \times 10^{5} \mathrm{cells} / \mathrm{cm}^{2}$ are co-transfected with the three plasmids at a concentration of $0.066 \mu \mathrm{g} / \mathrm{cm}^{2}$ (retroviral backbone vector), $0.09 \mu \mathrm{g} / \mathrm{cm}^{2}$ (packaging vector) and $0.044 \mu \mathrm{g} / \mathrm{cm}^{2}$ (env plasmid) using Invitrogen ${ }^{\mathrm{TM}}$ Lipofectamine $^{\mathrm{TM}} 2000$ Transfection Reagent, following manufacturer indications. $24 \mathrm{~h}$ post transfection, the media is replaced by a fresh harvest media that is normally used to cultivate the cells that will be infected. Viral particles are harvested at 48, 60 and $72 \mathrm{~h}$ after transfection by collecting the medium followed by filtration.

\subsection{Retroviral infection of PDX cells and GCPs}

To infect PDXs, $9 \mathrm{ml}$ of a cell suspension is prepared at $4.10^{6}$ cells $/ \mathrm{ml}$ and plated in $\mathrm{T} 75$ lowattaching flasks. Then, $1 \mathrm{ml}$ of viral particles is added to cell culture.

For GCP infection, a cell suspension at $2.10^{6} \mathrm{cells} / \mathrm{ml}$ is plated at $500 \mu 1 /$ well in a 12 -wells plate and incubated 30 minutes at $37^{\circ} \mathrm{C}$. Then, $250 \mu \mathrm{l}$ of viral suspension/well is added and plates are incubated $1 \mathrm{~h} 30$ at $37^{\circ} \mathrm{C}$, followed by the addition of another $250 \mu \mathrm{l}$ of viral suspension/well and an incubation for $1 \mathrm{~h} 30$ at $37^{\circ} \mathrm{C}$. Then, $500 \mu \mathrm{l}$ of media is removed and $250 \mu \mathrm{l}$ of viral suspension/well is again added. SHH is added to cells at a final concentration of $0.2 \mu \mathrm{g} / \mathrm{ml}$ and plates are incubated overnight at $37^{\circ} \mathrm{C}$. GCPs media is then removed and replaced by fresh media. Cells can be further processed for transplantation in mice.

\subsection{Preparing culture of PDX cells and GCPs for orthotopic grafting}


Cells to be orthotopically grafted are flushed and harvested. They are washed twice by centrifugation and resuspended in CMF-PBS at an adequate concentration to be injected. For GCP, $1.10^{6}$ cells $/ 5 \mu \mathrm{l} / \mathrm{mice}$ are used. For each PDX, adequate concentration shall be determined for reproducible tumor growth. We usually use $3.10^{5}$ cells $/ 5 \mu 1 /$ mice for the G3 PDXs available in our lab.

\subsection{Orthotopic grafting}

\subsubsection{Animal preparation}

Orthotopic transplants are performed in 7-8 weeks-old NMRI Nude female mice (Janvier Labs). Mice are acclimated to the animal facility at least one week before surgery. The grafting of tumor cells is performed under anesthesia. First, animals are anesthetized in an induction chamber (Anesthesia workstation AST-00, Anestéo) supplied with isoflurane (5\%), compressed air (11/min) and $\mathrm{O}_{2}(0.81 / \mathrm{min})$. For surgery, mice are placed in a stereotaxic frame supplied with a microinjection system (PHYMEP), while they are kept in inhalation masks (isoflurane 3-5\%) (Figure 1). Local anesthetic and analgesic are supplied before surgery such as Bupivacaine $(5 \mathrm{mg} / \mathrm{mL}$, Aguettant) and Buprecare $(0.3 \mathrm{mg} / \mathrm{mL}$, Axience), respectively. During anesthesia, an adequate body temperature of animals is maintained using heated pads (Anestéo) while heated lamps (Anestéo) are used during the awakening phase.

\section{(Figure 1)}

\subsubsection{Stereotaxic surgery}

As part of the pre-operative care, mice receive an intraperitoneal injection of $50 \mu 1$ of Buprecare. The animal is positioned by hooking its incisors in the frame hold and using ears bars. Once the animal is well fixed, additional local anesthetic is supplied: two injections of $30 \mu \mathrm{l}$ of Bupivacaine is performed subcutaneously at the level of the skull around the site of incision. The skin of this area is disinfected with a betadine solution (10\%, MEDA Pharma) and then, using surgical sterile scissors, an incision is performed along the midline to expose the skull. The pericranial transparent tissues are scraped with the help of a sterile cotton tip. Then, the exact area of injection is determined using stereotaxic referent coordinates: a small hole in the skull is made using a $25 \mathrm{G}$ needle at $2 \mathrm{~mm}$ lateral and $2 \mathrm{~mm}$ posterior to the Lambda (Figure 2). 
Then, a Hamilton syringe $1700(10 \mu 1,26 \mathrm{G})$ coupled to an automate injector is inserted in this emplacement, first to a depth of $3 \mathrm{~mm}$ and then raised to $2.5 \mathrm{~mm}$ to proceed with the injection of $5 \mu \mathrm{l}$ of cell suspension at a rate of $2.5 \mu \mathrm{l} / \mathrm{min}$. The syringe should remain in place for 2 additional minutes following injection, and then, gently removed ${ }^{4}$. The scission is closed using Horsley' bone wax (SMI) and the skin is closed with tissue glue (Surgibond) ${ }^{5}$.

\section{(Figure 2)}

\subsection{In vivo bioluminescence imaging using IVIS}

Cells orthotopically grafted in mice are engineered to express the luciferase gene, following infection with retrovirus encoding this gene (see above). This allows to follow tumor growth in a non-invasive manner using bioluminescence. Animals bearing tumor cells expressing the luciferase gene are injected with Luciferin, the substrate of the luciferase enzyme. During oxidation of luciferin catalyzed by Luciferase, light is emitted. The photons are captured using an IVIS Spectrum In Vivo Imaging System (Perkin Elmer) and images are subsequently analyzed using the Living Image software. The intensity of the signal is a direct measure of tumor size since Luciferase concentration (number of cells expressing the reporter gene) is linearly correlated to photon emission. Bioluminescence imaging and quantification are performed at different time points to follow tumor growth in a non-invasive manner. IVIS imaging of animals is performed under isoflurane anesthesia (2\%), 15 minutes after an IP administration of Luciferine $(30 \mathrm{mg} / \mathrm{ml} 50 \mu 1$, Perkin Elmer).

As mentioned above, genetic modifications of GCPs have been used in the field to investigate the different oncogenic hits cooperating with MYC to promote G3-MB formation. As an example, we present here the results obtained when GCPs overexpressing a stabilized form of MYC and GFI1 using two pMIGR constructs, are orthotopically grafted in the cerebellum of immunodeficient mice. One of the pMIGR construct coexpresses the Luciferase gene, allowing non-invasive follow-up of tumor growth by bioluminescence imaging (Figure 3). Thus, grafted mice develop tumors that are detectable by bioluminescence from day 20 after surgery with a signal increasing in time (Figure 3A). Quantification of bioluminescent signal is performed using the Living Image software. All images obtained from each animal at the different time points are analyzed by measuring the amount of photons emitted. To that end, an area of 
quantification (red circle - Region of Interest (ROI) - Figure 3B) is similarly applied to all mice in all images. This allows to measure the amount of photons emitted (Figure 3B).

Photon emission is then plotted at given time points, to obtain the variation of the bioluminescence signal, indicating the size of the developing tumors (Figure 3C). These types of experiments allow the follow-up of tumor growth without animal euthanasia. Animals are spared until they show clinical endpoints requiring euthanasia (Figure 3D).

(Figure 3)

\section{Troubleshooting}

${ }^{1}$ If tissue disaggregation is not satisfying after this step, the time of incubation could be increased and, in any case, should be optimized for each PDX.

${ }^{2}$ PDX MB primary cultures can be maintained in culture for a limited period of time; any experimental procedure with these cultures should be planned taking into account this feature.

${ }^{3}$ In order to obtain an adequate number of GCPs, the exact number of processed cerebella should be determined and optimized considering that cells yield depends on the mouse strain and pup age. In our conditions, the best results are obtained at P7. The dissection part could also be optimized to improve the final result.

${ }^{4}$ Animal respiration should be monitored all along the surgery. If respiration seems laborious, with an inefficient rhythm or if it stops completely, remove the animal rapidly from the stereotaxic frame and install it in a warm surface. A tail massage, from the end of the tail to the body, can be performed in order to help blood circulation. The thorax can be also compressed repeatedly.

${ }^{5}$ After surgery, recovery from anesthesia should be carefully monitored to detect any sign of suffering/distress. Possible symptoms after brain stereotaxic surgery could involve bowed head, reduced locomotion, or distress behaviors such as mice running in circle. In this case, animals should be isolated with minimal disturbance. If signs of pain are still detected the day after 
surgery, additional analgesic could be provided. If the mouse does not recover from these symptoms, euthanasia is required.

\section{Conclusions}

In conclusion, the experimental procedures presented here allow to study the role of different players in MB biology in vivo. For example, potential oncogenic hits that are susceptible to cooperate with MYC to induce MB can be validated and, more generally, specific groups of MB can be modeled.

\section{REFERENCES}

1. Archer TC, Ehrenberger T, Mundt F, Gold MP, Krug K, Mah CK, Mahoney EL, Daniel CJ, LeNail A, Ramamoorthy D, Mertins P, Mani DR, Zhang H, Gillette MA, Clauser K, Noble M, Tang LC, Pierre-François J, Silterra J, Jensen J, Tamayo P, Korshunov A, Pfister SM, Kool M, Northcott PA, Sears RC, Lipton JO, Carr SA, Mesirov JP, Pomeroy SL, Fraenkel E (2018) Proteomics, Post-translational Modifications, and Integrative Analyses Reveal Molecular Heterogeneity within Medulloblastoma Subgroups. Cancer Cell 34:396-410.e8. doi: 10.1016/j.ccell.2018.08.004

2. Brabetz S, Leary SES, Gröbner SN, Nakamoto MW, Şeker-Cin H, Girard EJ, Cole B, Strand AD, Bloom KL, Hovestadt V, Mack NL, Pakiam F, Schwalm B, Korshunov A, Balasubramanian GP, Northcott PA, Pedro KD, Dey J, Hansen S, Ditzler S, Lichter P, Chavez L, Jones DTW, Koster J, Pfister SM, Kool M, Olson JM (2018) A biobank of patient-derived pediatric brain tumor models. Nat Med 24:1752-1761. doi: 10.1038/s41591-018-0207-3

3. Cavalli FMG, Remke M, Rampasek L, Peacock J, Shih DJH, Luu B, Garzia L, Torchia J, Nor C, Morrissy AS, Agnihotri S, Thompson YY, Kuzan-Fischer CM, Farooq H, Isaev K, Daniels C, Cho B-K, Kim S-K, Wang K-C, Lee JY, Grajkowska WA, Perek-Polnik M, Vasiljevic A, Faure-Conter C, Jouvet A, Giannini C, Nageswara Rao AA, Li KKW, Ng H-K, Eberhart CG, Pollack IF, Hamilton RL, Gillespie GY, Olson JM, Leary S, Weiss WA, Lach B, Chambless LB, Thompson RC, Cooper MK, Vibhakar R, Hauser P, van Veelen M-LC, Kros JM, French PJ, Ra YS, Kumabe T, López-Aguilar E, Zitterbart K, Sterba J, Finocchiaro G, Massimino M, Van Meir EG, Osuka S, Shofuda T, Klekner A, Zollo M, Leonard JR, Rubin JB, Jabado N, Albrecht S, Mora J, Van Meter TE, Jung S, Moore AS, Hallahan AR, Chan JA, Tirapelli DPC, Carlotti CG, Fouladi M, Pimentel J, Faria CC, Saad AG, Massimi L, Liau LM, Wheeler H, Nakamura H, Elbabaa SK, Perezpeña-Diazconti M, Chico Ponce de León F, Robinson S, Zapotocky M, Lassaletta A, Huang A, Hawkins CE, Tabori U, Bouffet E, Bartels U, Dirks PB, Rutka JT, Bader GD, Reimand J, Goldenberg A, Ramaswamy V, Taylor MD (2017) Intertumoral Heterogeneity within Medulloblastoma Subgroups. Cancer Cell 31:737-754.e6. doi: 10.1016/j.ccell.2017.05.005

4. Cho YJ, Tsherniak A, Tamayo P, Santagata S, Ligon A, Greulich H, Berhoukim R, Amani V, Goumnerova L, Eberhart CG, Lau CC, Olson JM, Gilbertson RJ, Gajjar A, Delattre O, Kool M, Ligon K, Meyerson M, Mesirov JP, Pomeroy SL (2010) Integrative Genomic 
Analysis of Medulloblastoma Identifies a Molecular Subgroup That Drives Poor Clinical Outcome. J Clin Oncol. 29:1424-30. doi: 10.1200/JCO.2010.28.5148

5. Cook Sangar ML, Genovesi LA, Nakamoto MW, Davis MJ, Knobluagh SE, Ji P, Millar A, Wainwright BJ, Olson JM (2017) Inhibition of CDK4/6 by Palbociclib Significantly Extends Survival in Medulloblastoma Patient-Derived Xenograft Mouse Models. Clin Cancer Res Off J Am Assoc Cancer Res 23:5802-5813. doi: 10.1158/1078-0432.CCR$16-2943$

6. Dörner L, Fritsch MJ, Stark AM, Mehdorn HM (2007) Posterior fossa tumors in children: how long does it take to establish the diagnosis? Childs Nerv Syst ChNS Off J Int Soc Pediatr Neurosurg 23:887-890. doi: 10.1007/s00381-007-0323-8

7. Forget A, Martignetti L, Puget S, Calzone L, Brabetz S, Picard D, Montagud A, Liva S, Sta A, Dingli F, Arras G, Rivera J, Loew D, Besnard A, Lacombe J, Pagès M, Varlet P, Dufour C, Yu H, Mercier AL, Indersie E, Chivet A, Leboucher S, Sieber L, Beccaria K, Gombert M, Meyer FD, Qin N, Bartl J, Chavez L, Okonechnikov K, Sharma T, Thatikonda V, Bourdeaut F, Pouponnot C, Ramaswamy V, Korshunov A, Borkhardt A, Reifenberger G, Poullet P, Taylor MD, Kool M, Pfister SM, Kawauchi D, Barillot E, Remke M, Ayrault O (2018) Aberrant ERBB4-SRC Signaling as a Hallmark of Group 4 Medulloblastoma Revealed by Integrative Phosphoproteomic Profiling. Cancer Cell 34:379-395.e7. doi: 10.1016/j.ccell.2018.08.002

8. Garancher A, Lin CY, Morabito M, Richer W, Rocques N, Larcher M, Bihannic L, Smith K, Miquel C, Leboucher S, Herath NI, Dupuy F, Varlet P, Haberler C, Walczak C, El Tayara N, Volk A, Puget S, Doz F, Delattre O, Druillennec S, Ayrault O, Wechsler-Reya RJ, Eychène A, Bourdeaut F, Northcott PA, Pouponnot C (2018) NRL and CRX Define Photoreceptor Identity and Reveal Subgroup-Specific Dependencies in Medulloblastoma. Cancer Cell 33:435-449.e6. doi: 10.1016/j.ccell.2018.02.006

9. Gibson P, Tong Y, Robinson G, Thompson MC, Currle DS, Eden C, Kranenburg TA, Hogg T, Poppleton H, Martin J, Finkelstein D, Pounds S, Weiss A, Patay Z, Scoggins M, Ogg R, Pei Y, Yang ZJ, Brun S, Lee Y, Zindy F, Lindsey JC, Taketo MM, Boop FA, Sanford RA, Gajjar A, Clifford SC, Roussel MF, McKinnon PJ, Gutmann DH, Ellison DW, Wechsler-Reya R, Gilbertson RJ (2010) Subtypes of medulloblastoma have distinct developmental origins. Nature 468:1095-9. doi: 10.1038/nature09587

10. Goodrich LV, Milenković L, Higgins KM, Scott MP (1997) Altered neural cell fates and medulloblastoma in mouse patched mutants. Science 277:1109-1113. doi: 10.1126/science.277.5329.1109

11. Kawauchi D, Ogg RJ, Liu L, Shih DJH, Finkelstein D, Murphy BL, Rehg JE, Korshunov A, Calabrese C, Zindy F, Phoenix T, Kawaguchi Y, Gronych J, Gilbertson RJ, Lichter P, Gajjar A, Kool M, Northcott PA, Pfister SM, Roussel MF (2017) Novel MYC-driven medulloblastoma models from multiple embryonic cerebellar cells. Oncogene 36:52315242. doi: 10.1038/onc.2017.110

12. Kawauchi D, Robinson G, Uziel T, Gibson P, Rehg J, Gao C, Finkelstein D, Qu C, Pounds S, Ellison DW, Gilbertson RJ, Roussel MF (2012) A mouse model of the most aggressive subgroup of human medulloblastoma. Cancer Cell 21:168-80. doi: 10.1016/j.ccr.2011.12.023 
13. Kersten K, de Visser KE, van Miltenburg MH, Jonkers J (2017) Genetically engineered mouse models in oncology research and cancer medicine. EMBO Mol Med 9:137-153. doi: $10.15252 / \mathrm{emmm} .201606857$

14. Kool M, Jones DTW, Jäger N, Northcott PA, Pugh TJ, Hovestadt V, Piro RM, Esparza LA, Markant SL, Remke M, Milde T, Bourdeaut F, Ryzhova M, Sturm D, Pfaff E, Stark S, Hutter S, Seker-Cin H, Johann P, Bender S, Schmidt C, Rausch T, Shih D, Reimand J, Sieber L, Wittmann A, Linke L, Witt H, Weber UD, Zapatka M, König R, Beroukhim R, Bergthold G, van Sluis P, Volckmann R, Koster J, Versteeg R, Schmidt S, Wolf S, Lawerenz C, Bartholomae CC, von Kalle C, Unterberg A, Herold-Mende C, Hofer S, Kulozik AE, von Deimling A, Scheurlen W, Felsberg J, Reifenberger G, Hasselblatt M, Crawford JR, Grant GA, Jabado N, Perry A, Cowdrey C, Croul S, Zadeh G, Korbel JO, Doz F, Delattre O, Bader GD, McCabe MG, Collins VP, Kieran MW, Cho Y-J, Pomeroy SL, Witt O, Brors B, Taylor MD, Schüller U, Korshunov A, Eils R, Wechsler-Reya RJ, Lichter P, Pfister SM, ICGC PedBrain Tumor Project (2014) Genome sequencing of SHH medulloblastoma predicts genotype-related response to smoothened inhibition. Cancer Cell 25:393-405. doi: 10.1016/j.ccr.2014.02.004

15. Kool M, Koster J, Bunt J, Hasselt NE, Lakeman A, van Sluis P, Troost D, Meeteren NS, Caron HN, Cloos J, Mrsic A, Ylstra B, Grajkowska W, Hartmann W, Pietsch T, Ellison D, Clifford SC, Versteeg R (2008) Integrated genomics identifies five medulloblastoma subtypes with distinct genetic profiles, pathway signatures and clinicopathological features. PLoS ONE 3:e3088. doi: 10.1371/journal.pone.0003088

16. Landau NR, Littman DR (1992) Packaging system for rapid production of murine leukemia virus vectors with variable tropism. J Virol 66:5110-5113

17. Northcott PA, Buchhalter I, Morrissy AS, Hovestadt V, Weischenfeldt J, Ehrenberger T, Gröbner S, Segura-Wang M, Zichner T, Rudneva VA, Warnatz H-J, Sidiropoulos N, Phillips AH, Schumacher S, Kleinheinz K, Waszak SM, Erkek S, Jones DTW, Worst BC, Kool M, Zapatka M, Jäger N, Chavez L, Hutter B, Bieg M, Paramasivam N, Heinold M, Gu Z, Ishaque N, Jäger-Schmidt C, Imbusch CD, Jugold A, Hübschmann D, Risch T, Amstislavskiy V, Gonzalez FGR, Weber UD, Wolf S, Robinson GW, Zhou X, Wu G, Finkelstein D, Liu Y, Cavalli FMG, Luu B, Ramaswamy V, Wu X, Koster J, Ryzhova M, Cho Y-J, Pomeroy SL, Herold-Mende C, Schuhmann M, Ebinger M, Liau LM, Mora J, McLendon RE, Jabado N, Kumabe T, Chuah E, Ma Y, Moore RA, Mungall AJ, Mungall KL, Thiessen N, Tse K, Wong T, Jones SJM, Witt O, Milde T, Von Deimling A, Capper D, Korshunov A, Yaspo M-L, Kriwacki R, Gajjar A, Zhang J, Beroukhim R, Fraenkel E, Korbel JO, Brors B, Schlesner M, Eils R, Marra MA, Pfister SM, Taylor MD, Lichter P (2017) The whole-genome landscape of medulloblastoma subtypes. Nature 547:311-317. doi: 10.1038/nature22973

18. Northcott PA, Korshunov A, Witt H, Hielscher T, Eberhart CG, Mack S, Bouffet E, Clifford SC, Hawkins CE, French P, Rutka JT, Pfister S, Taylor MD (2010) Medulloblastoma Comprises Four Distinct Molecular Variants. J Clin Oncol 29:1408-14. doi: 10.1200/JCO.2009.27.4324

19. Northcott PA, Lee C, Zichner T, Stütz AM, Erkek S, Kawauchi D, Shih DJH, Hovestadt V, Zapatka M, Sturm D, Jones DTW, Kool M, Remke M, Cavalli FMG, Zuyderduyn S, Bader GD, VandenBerg S, Esparza LA, Ryzhova M, Wang W, Wittmann A, Stark S, Sieber L, Seker-Cin H, Linke L, Kratochwil F, Jäger N, Buchhalter I, Imbusch CD, 
Zipprich G, Raeder B, Schmidt S, Diessl N, Wolf S, Wiemann S, Brors B, Lawerenz C, Eils J, Warnatz H-J, Risch T, Yaspo M-L, Weber UD, Bartholomae CC, von Kalle C, Turányi E, Hauser P, Sanden E, Darabi A, Siesjö P, Sterba J, Zitterbart K, Sumerauer D, van Sluis P, Versteeg R, Volckmann R, Koster J, Schuhmann MU, Ebinger M, Grimes HL, Robinson GW, Gajjar A, Mynarek M, von Hoff K, Rutkowski S, Pietsch T, Scheurlen W, Felsberg J, Reifenberger G, Kulozik AE, von Deimling A, Witt O, Eils R, Gilbertson RJ, Korshunov A, Taylor MD, Lichter P, Korbel JO, Wechsler-Reya RJ, Pfister SM (2014) Enhancer hijacking activates GFI1 family oncogenes in medulloblastoma. Nature 511:428-434. doi: 10.1038/nature13379

20. Northcott PA, Robinson GW, Kratz CP, Mabbott DJ, Pomeroy SL, Clifford SC, Rutkowski S, Ellison DW, Malkin D, Taylor MD, Gajjar A, Pfister SM (2019) Medulloblastoma. Nat Rev Dis Primer 5:11. doi: 10.1038/s41572-019-0063-6

21. Pei Y, Moore CE, Wang J, Tewari AK, Eroshkin A, Cho YJ, Witt H, Korshunov A, Read TA, Sun JL, Schmitt EM, Miller CR, Buckley AF, McLendon RE, Westbrook TF, Northcott PA, Taylor MD, Pfister SM, Febbo PG, Wechsler-Reya RJ (2012) An animal model of MYC-driven medulloblastoma. Cancer Cell 21:155-67. doi: 10.1016/j.ccr.2011.12.021

22. Reya T, Duncan AW, Ailles L, Domen J, Scherer DC, Willert K, Hintz L, Nusse R, Weissman IL (2003) A role for Wnt signalling in self-renewal of haematopoietic stem cells. Nature 423:409-414. doi: 10.1038/nature01593

23. Rivero-Hinojosa S, Lau LS, Stampar M, Staal J, Zhang H, Gordish-Dressman H, Northcott PA, Pfister SM, Taylor MD, Brown KJ, Rood BR (2018) Proteomic analysis of Medulloblastoma reveals functional biology with translational potential. Acta Neuropathol Commun 6:48. doi: 10.1186/s40478-018-0548-7

24. Schuller U, Heine VM, Mao J, Kho AT, Dillon AK, Han YG, Huillard E, Sun T, Ligon AH, Qian Y, Ma Q, Alvarez-Buylla A, McMahon AP, Rowitch DH, Ligon KL (2008) Acquisition of granule neuron precursor identity is a critical determinant of progenitor cell competence to form Shh-induced medulloblastoma. Cancer Cell 14:123-34. doi: 10.1016/j.ccr.2008.07.005

25. Schwalbe EC, Lindsey JC, Nakjang S, Crosier S, Smith AJ, Hicks D, Rafiee G, Hill RM, Iliasova A, Stone T, Pizer B, Michalski A, Joshi A, Wharton SB, Jacques TS, Bailey S, Williamson D, Clifford SC (2017) Novel molecular subgroups for clinical classification and outcome prediction in childhood medulloblastoma: a cohort study. Lancet Oncol 18:958-971. doi: 10.1016/S1470-2045(17)30243-7

26. Schwalbe EC, Williamson D, Lindsey JC, Hamilton D, Ryan SL, Megahed H, Garami M, Hauser P, Dembowska-Baginska B, Perek D, Northcott PA, Taylor MD, Taylor RE, Ellison DW, Bailey S, Clifford SC (2013) DNA methylation profiling of medulloblastoma allows robust subclassification and improved outcome prediction using formalin-fixed biopsies. Acta Neuropathol (Berl) 125:359-371. doi: 10.1007/s00401-012-1077-2

27. Swartling FJ, Grimmer MR, Hackett CS, Northcott PA, Fan QW, Goldenberg DD, Lau J, Masic S, Nguyen K, Yakovenko S, Zhe XN, Gilmer HC, Collins R, Nagaoka M, Phillips JJ, Jenkins RB, Tihan T, Vandenberg SR, James CD, Tanaka K, Taylor MD, Weiss WA, 
Chesler L (2010) Pleiotropic role for MYCN in medulloblastoma. Genes Dev 24:105972. doi: $10.1101 / \mathrm{gad} .1907510$

28. Swartling FJ, Savov V, Persson AI, Chen J, Hackett CS, Northcott PA, Grimmer MR, Lau J, Chesler L, Perry A, Phillips JJ, Taylor MD, Weiss WA (2012) Distinct neural stem cell populations give rise to disparate brain tumors in response to N-MYC. Cancer Cell 21:601-613. doi: 10.1016/j.ccr.2012.04.012

29. Taylor MD, Northcott PA, Korshunov A, Remke M, Cho YJ, Clifford SC, Eberhart CG, Parsons DW, Rutkowski S, Gajjar A, Ellison DW, Lichter P, Gilbertson RJ, Pomeroy SL, Kool M, Pfister SM (2011) Molecular subgroups of medulloblastoma: the current consensus. Acta Neuropathol 123:465-72. doi: 10.1007/s00401-011-0922-z

30. Thompson MC, Fuller C, Hogg TL, Dalton J, Finkelstein D, Lau CC, Chintagumpala M, Adesina A, Ashley DM, Kellie SJ, Taylor MD, Curran T, Gajjar A, Gilbertson RJ (2006) Genomics identifies medulloblastoma subgroups that are enriched for specific genetic alterations. J Clin Oncol 24:1924-31. doi: 10.1200/JCO.2005.04.4974

31. Vo BT, Li C, Morgan MA, Theurillat I, Finkelstein D, Wright S, Hyle J, Smith SMC, Fan Y, Wang Y-D, Wu G, Orr BA, Northcott PA, Shilatifard A, Sherr CJ, Roussel MF (2017) Inactivation of Ezh2 Upregulates Gfi1 and Drives Aggressive Myc-Driven Group 3 Medulloblastoma. Cell Rep 18:2907-2917. doi: 10.1016/j.celrep.2017.02.073

32. Wang J, Garancher A, Ramaswamy V, Wechsler-Reya RJ (2018) Medulloblastoma: From Molecular Subgroups to Molecular Targeted Therapies. Annu Rev Neurosci 41:207-232. doi: 10.1146/annurev-neuro-070815-013838

33. Ward E, DeSantis C, Robbins A, Kohler B, Jemal A (2014) Childhood and adolescent cancer statistics, 2014. CA Cancer J Clin 64:83-103. doi: 10.3322/caac.21219

34. Yang ZJ, Ellis T, Markant SL, Read TA, Kessler JD, Bourboulas M, Schuller U, Machold R, Fishell G, Rowitch DH, Wainwright BJ, Wechsler-Reya RJ (2008) Medulloblastoma can be initiated by deletion of Patched in lineage-restricted progenitors or stem cells. Cancer Cell 14:135-45. doi: 10.1016/j.ccr.2008.07.003

35. Zhao X, Liu Z, Yu L, Zhang Y, Baxter P, Voicu H, Gurusiddappa S, Luan J, Su JM, Leung HE, Li X-N (2012) Global gene expression profiling confirms the molecular fidelity of primary tumor-based orthotopic xenograft mouse models of medulloblastoma. NeuroOncol 14:574-583. doi: 10.1093/neuonc/nos061

36. Zindy F, Uziel T, Ayrault O, Calabrese C, Valentine M, Rehg JE, Gilbertson RJ, Sherr CJ, Roussel MF (2007) Genetic alterations in mouse medulloblastomas and generation of tumors de novo from primary cerebellar granule neuron precursors. Cancer Res 67:26762684. doi: 10.1158/0008-5472.CAN-06-3418

\section{Acknowledgements}


We thank members of our laboratory for helpful advice and comments. This work was supported by grants from Ligue Nationale Contre le Cancer (Val d'Oise 2019 - Oise-Yvelines \#M18759, \#M16649 and Legs Chovet), Institut National du Cancer (INCa, Pair Pediatrie, Mr ROBOT), the IRS "NanoTheRad" of University U-PSUD (Paris-Saclay) and Gefluc Ile de France, Association AIDA. LMO and MM were supported by a fellowship from the Ministère Français de l'Enseignement Supérieur, de la Recherche et de l'Innovation and Fondation ARC (4th year $\mathrm{PhD}$ fellowship).

\section{Figure legends}

Figure 1: Stereotaxic surgery area and animal preparation. For anesthesia mice are placed in an induction chamber supplied with isoflurane (5\%), compressed air (11/min) and $\mathrm{O} 2$ $(0.81 / \mathrm{min})$. For the surgery, anesthetized animals are placed in a stereotaxic frame, while kept in inhalation masks (isoflurane 3-5\%) and the exact coordinates of injection are determined.

Figure 2: Site of injection for orthotopic grafting in the cerebellum. The site of injection is determined using the lambda point as a referent. From here, stereotaxic coordinates are determined and cells are injected at $2 \mathrm{~mm}$ lateral (X) and $2 \mathrm{~mm}$ posterior ( $\mathrm{Y}$ ) to the Lambda and at a depth of $2.5 \mathrm{~mm}(\mathrm{Z})$.

Figure 3: Orthotopic grafting of GCPs overexpressing MYC and GFI1 lead to Medulloblastoma formation in immunodeficient mice. A and B. Tumor growth was followed by Bioluminescence IVIS Imaging. A. Images of luciferase signal in representative animals at the indicated days. B. Representatives images shown in A with the selected area of photons measurement (Region of Interest, ROI). C. Number of photons measured as indicated in B for all the animals in the experiment $(n=12)$ during time. D. Kaplan-Meier survival curves of these animals. 


\section{Figure 1}

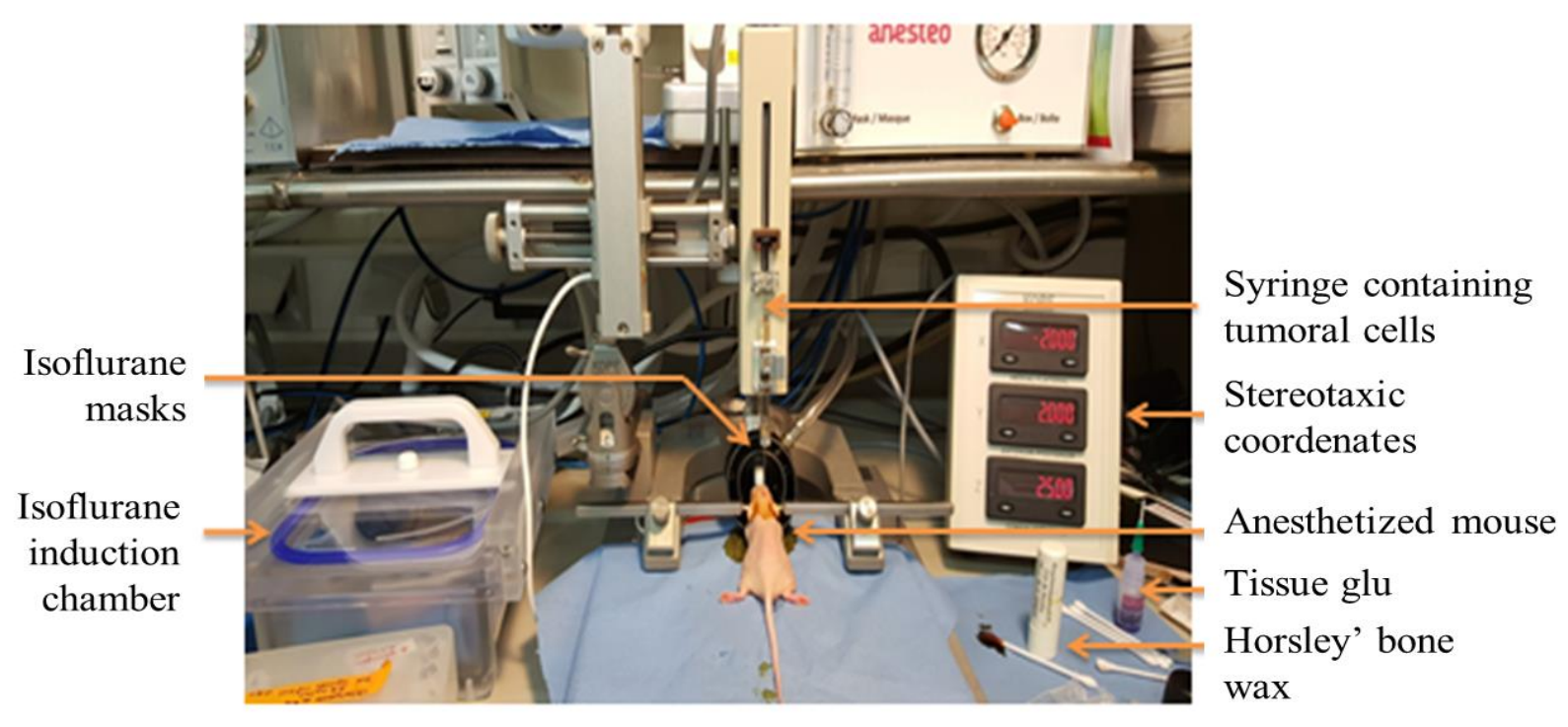


Figure 2

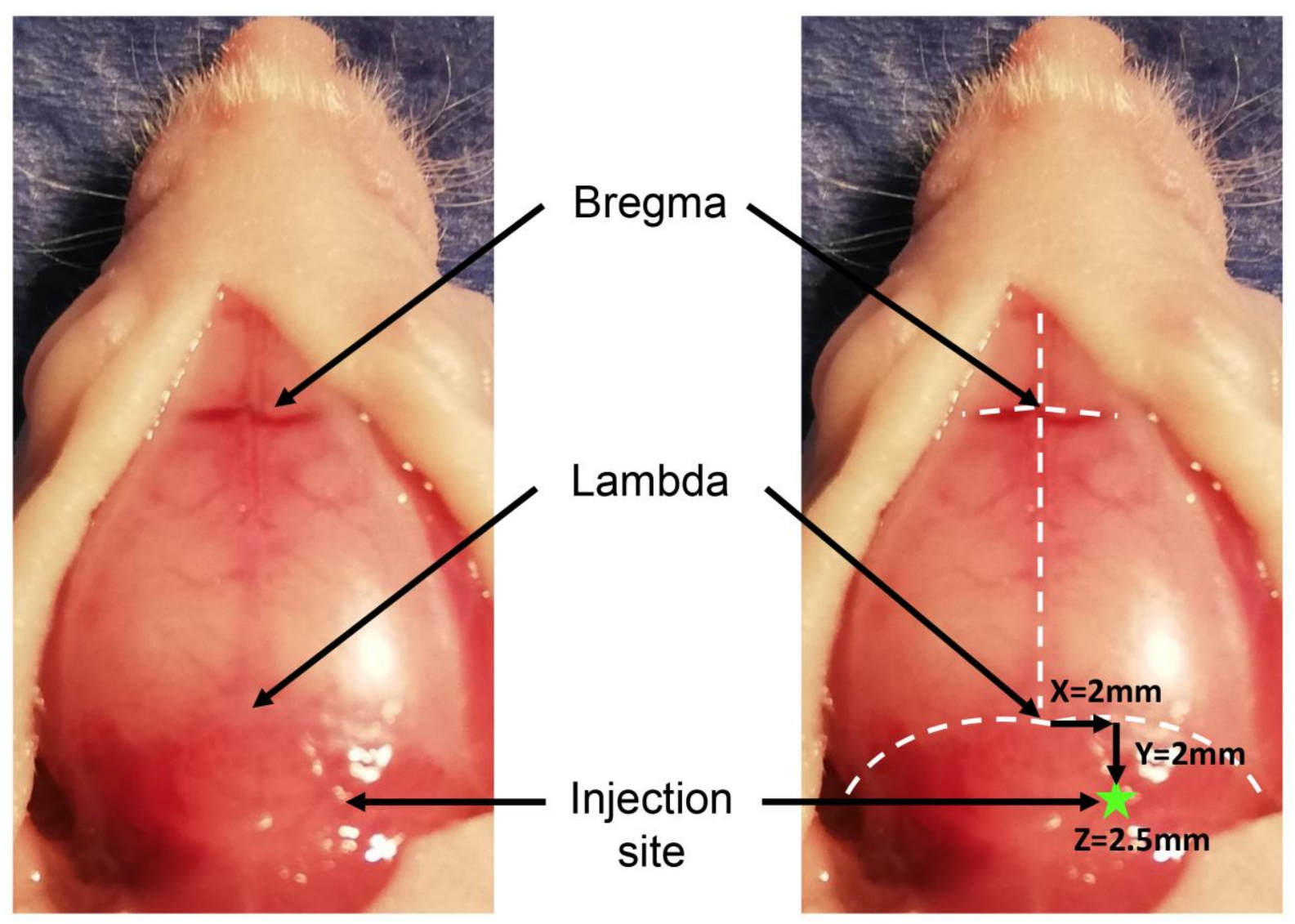


Figure 3

A

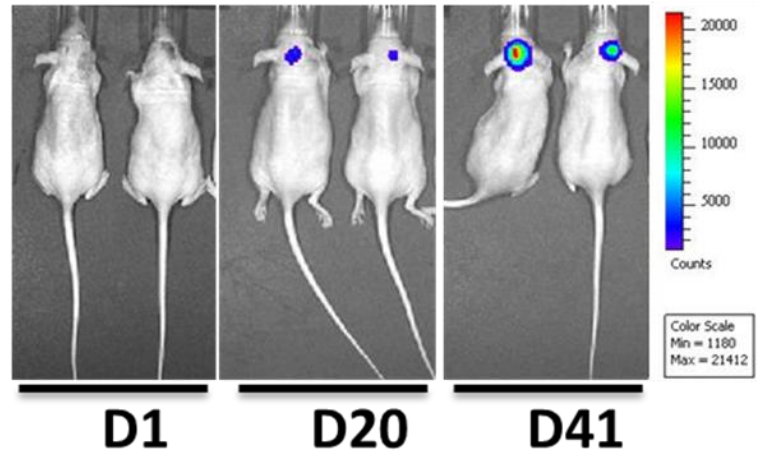

C

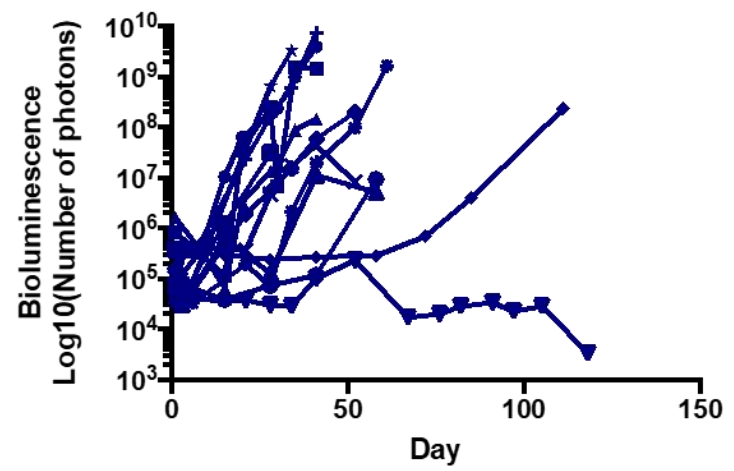

B

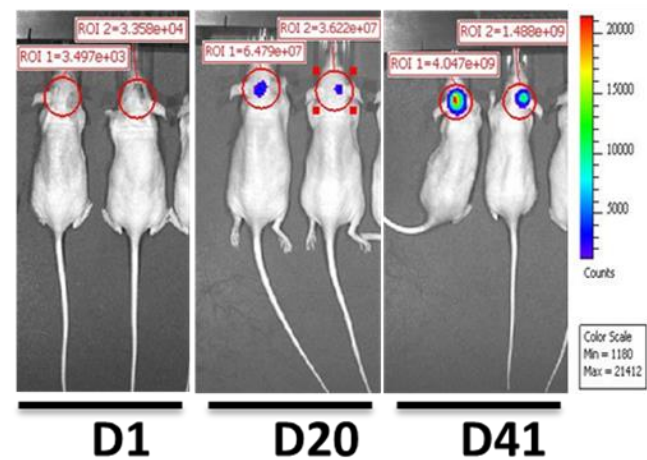

D

GcP luc-MYCT58A/GFi1 $(n=13)$

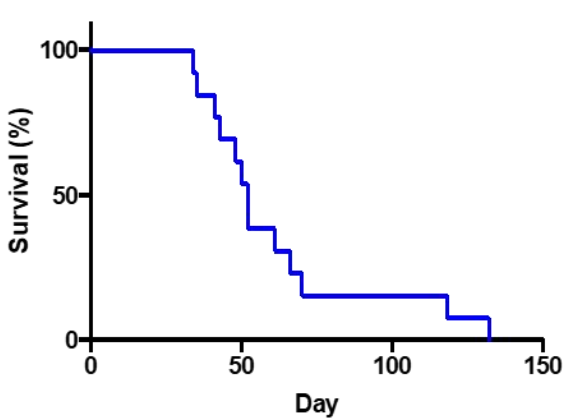


$\underline{\text { Table } 1 \text { Main clinic and molecular features of Medulloblastoma subgroups }}$

\begin{tabular}{|c|c|c|c|c|}
\hline & WNT & SHH & G3 & G4 \\
\hline Age at diagnosis & $\begin{array}{l}\text { Children and } \\
\text { adults }\end{array}$ & $\begin{array}{l}\text { Infants, children } \\
\text { and adults }\end{array}$ & $\begin{array}{l}\text { Infants and } \\
\text { children }\end{array}$ & Children \\
\hline Incidence & $10-15 \%$ & $25-30 \%$ & $20-25 \%$ & $35-40 \%$ \\
\hline Metastasis at diagnosis & $5-10 \%$ & $20 \%$ & $40-50 \%$ & $35-40 \%$ \\
\hline $\begin{array}{c}\text { Overall survival (5 } \\
\text { years) }\end{array}$ & Very good/95\% & Intermediate $/ 75 \%$ & Poor $/ 50 \%$ & Intermediate $/ 75 \%$ \\
\hline Histology & Classic & $\begin{array}{c}\text { Classic, } \\
\text { desmoplastic, } \\
\text { LC/A }\end{array}$ & Classic, LC/A & Classic, LC/A \\
\hline Proposed cell of origin & $\begin{array}{l}\text { Lower rhombic } \\
\text { lip progenitors }\end{array}$ & $\begin{array}{l}\text { Granule cells } \\
\text { progenitors }\end{array}$ & Neural stem cells & Not yet determined \\
\hline $\begin{array}{l}\text { Main molecular } \\
\text { drivers }\end{array}$ & CTNNB1 & PTCH1 & $M Y C$ & PRDM6, SRC \\
\hline Expression signature & WNT signaling & SHH signaling & $\begin{array}{l}\text { Photoreceptor/ } \\
\text { GABAergic }\end{array}$ & $\begin{array}{l}\text { Neuronal/ } \\
\text { glutamergic }\end{array}$ \\
\hline
\end{tabular}

